\title{
STRATEGI KOMUNIKASI PEMASARAN DALAM MENINGKATKAN JUMLAH SISWA (Studi Kasus pada Bimbingan Belajar Bintang Solusi Mandiri Cabang Pinang, Jakarta)
}

\author{
Saktisyahputra \\ Prodi Manajemen Komunikasi, Institut Ilmu Sosial dan Manajemen Stiami \\ Email: saktinabil@gmail.com, saktisyahputra@stiami.ac.id
}

ARTICLE INFO ABSTRACT

Keywords:

Strategy,

Marketing,Communication

\begin{abstract}
Non-formal institutions such as a tutorial should always be ready with the changes issued by the government in the field of education. It should also be ready to compete with other tutorial and schools who offer tutorial services. To the authors chose the title "Marketing Communication Strategy Training and Tutoring Institute (Bimbel Solusi) Bintang Solusi Mandiri Branch Cipinang to Increase the Number of Students". Basic Theory used in this research is the theory of Marketing Mix according to Kotler Keller and SWOT Analysis by Fred R David. The method used in this research is qualitative - interpretive using case studies. Results of this research is Communication Strategy Training Institute and Tutoring Bintang Solusi Mandiri Branch Cipinang month of August 2018, namely the Direct Selling to residential introduce Tutoring (Bimbel) Solution through brochures, presentation Bimbel Solusi for each class in the school - the school through brochures, Distribution the share of school construction amounted to Rp.50.000 / student who joined Bimbel Solusi Branch Cipinang, follow-up database of students in the school by telephone and short message service (SMS) and then factor - a factor which supports the Institute for Training and Tutoring Bintang Solusi Mandiri Branch Cipinang in the areas of Strategy MarketingCommunication to increase the number of students is a factor of the program.
\end{abstract}

\section{PENDAHULUAN}

Konsep Tri Pusat Pendidikan yang dicetuskan oleh Bapak Pendidikan Nasional, Ki Hajar Dewantara menyatakan bahwa peletak dasar pendidikan menjadi tanggung jawab bersama antara sekolah, keluarga dan masyarakat dalam hal ini lembaga bimbingan belajar. Masing-masing wadah pendidikan mempunyai wilayah dan mekanisme penyelenggaraan pendidikan yang berbeda, namun tujuan akhirnya sama yaitu ingin menciptakan manusia yang unggul atau mempunyai keunggulan kompetitif untuk membangun bangsa dan negara Indonesia.

Perubahan-perubahan pola pendidikan yang begitu cepat, silih berganti serta globalisasi di segala bidang termasuk bidang pendidikan, memunculkan persaingan yang sangat ketat di bidang bisnis jasa pendidikan. Lembaga non-formal seperti bimbingan belajar harus selalu siap dengan perubahan-perubahan yang dikeluarkan pemerintah di bidang pendidikan. Bimbingan belajar harus siap bersaing tidak hanya dengan bimbingan belajar sejenis, tetapi juga dengan sekolah yang menyelenggarakan bimbingan belajar.

Menurut UUD 1945 pasal 31 dan UU No. 2 tahun 2003 tentang sistem pendidikan nasional (sisdiknas) bahwa penyelenggaraan pendidikan menjadi tanggung jawab bersama antara pemerintah dan masyarakat. Hal tersebut menunjukkan bahwa penyelenggaraan pendidikan tidak hanya di sekolah formal saja tetapi juga dapat diselenggarakan oleh lembaga luar sekolah semacam Bimbingan Belajar. Lembaga bimbingan belajar mempunyai dasar yang kuat sebagai wujud partisipasi masyarakat dalam mencerdaskan kehidupan bangsa.

Kondisi pendidikan di Indonesia saat ini jauh dari substansi tujuan pendidikan yang tertera dalam Pembukaan UUD 1945 yaitu, "mencerdaskan kehidupan bangsa". Hal tersebut terlihat dari segala aspek yang berkaitan dengan pendidikan, seperti komersialisasi pendidikan, pendidikan sebagai 
penyedia tenaga kerja, pendidikan yang di serahkan pada mekanisme pasar bebas, dan pendidikan sebagai lahan industrialisasi. Kondisi pendidikan Indonesia tidak lepas dari kebijakan-kebijakan Pemerintah dalam mengatur sistem pendidikan nasional yang tidak berkiblat pada kepentingan masyarakat. Pemerintah seharusnya dapat memperbaiki sistem pendidikan di Indonesia agar mampu menciptakan sumber daya yang kompeten dan mampu bersaing.

Menurut Sekretaris Direktorat Jendral Perguruan Tinggi Dr. Ir. Patdono Suwignjo, Meter. Eng, Sc di Jakarta, dalam laporan paling baru Acara Pembangunan PBB thn 2013, Indonesia menempati posisi 121 dari 185 negeri dalam Indeks Pembangunan Manusia (IPM) dengan angka 0,629. Bersama angka itu Indonesia tertinggal dari dua negeri tetangga ASEAN yakni Malaysia (peringkat 64) dan Singapura (18), sedangkan IPM di kawasan Asia Pasifik yaitu 0,.683. (1)

Titik lemah kualitas pembangunan manusia Indonesia sebetulnya ada pada sektor pendidikan. Pencapaian kita dalam sektor ini masih sangat rendah. Hal ini menjadi persoalan serius karena kunci kemajuan suatu bangsa ada pada sektor pendidikan yang tangguh.

Menurut UNDP, rata-rata lama sekolah orang Indonesia hanya mencapai 5,8 tahun. Itu artinya, sebagain besar orang Indonesia tidak tamat Sekolah Dasar (SD). Begitu pula dengan harapan lama sekolah yang hanya sebesar 13,2 tahun. Ini menunjukkan secara umum orang Indonesia hanya akan mengenyam pendidikan sampai tingkat Sekolah Menengah Atas (SMA) saja. Statistik ini sangat realistis jika dikaitkan dengan sulitnya akses mengenyam pendidikan di perguruan tinggi saat ini karena tingginya biaya kuliah.

Terbatasnya akses pendidikan di Indonesia, terlebih di daerah, berujung pada meningkatnya arus urbanisasi untuk mendapatkan ilmu yang lebih baik di perkotaan. Di sudut lain, kasus putus sekolah anak- anak usia sekolah di Indonesia masih terbilang tinggi. Berdasarkan data Kemendikbud 2010, di Indonesia terdapat lebih dari 1,8 juta anak tiap tahunnya tidak mampu menyambung pendidikan. Hal tersebut disebabkan oleh tiga faktor, yaitu ; aspek ekonomi; anak - anak terpaksa bekerja untuk mendukung ekonomi keluarga serta pernikahan di umur dini. Di sisi lain kompetitor seperti Lembaga Pendidikan Primagama, Nurul Fikri dan Bimbingan Belajar Prestasi juga terus meningkatkan inovasi terutama strategi pemasaran dan promosi dalam meningkatkan minat siswa.

Menurut Arif Sunarto, Guru Bahasa Inggris di Lembaga Pendidikan Primagama Pusat, Yogyakarta bahwa strategi pemasaran dan promosi Lembaga Pendidikan Primagama yaitu menjadi sponsorhip program televisi cerdas cermat di Rajawali Televisi (RTV), menyebar brosur saat pembagian rapor di sekolah, melakukan demo smart dan smart consys serta melalui pendekatan rumus-rumus fisika dengan nama fisitaru magasing. Sampai saat ini jumlah siswa SD dan SMP Lembaga Pendidikan Primagama rata-rata per cabangnya yaitu sekitar yaitu 200 siswa.

Direktur Bimbingan Belajar Prestasi Ahmad Mahlili Yusup menyatakan bahwa strategi pemasaran dan promosi mereka mulai dengan kelas gratis, "closing" dengan membagi rapor bimbel, kerjasama dengan sekolah melalui titip brosur, membawa bingkisan ke sekolah, membawa program semacam Karya Ilmiah Remaja (KIR), Tes Gaya Belajar, memberikan piagam, promo awal semester, memberi insentif ke sekolah setiap ada siswa yang daftar, lalu mengajarkan admin untuk closing dan rutin membuat program setiap hari nasional. Menurut Mahlili yang paling awal dari strategi pemasaran dan promosi yang dilakukan oleh Bimbingan Belajar (Bimbel) Prestasi adalah SEDEKAH DI AWAL, yaitu menggratiskan 30 anak yatim dan dhuafa untuk les di Bimbel Prestasi. Anak-anak tersebut dimintai tolong titip brosur untuk bagi rapor sekalian membawakan aksesoris Bimbel Prestasi. Menurut Adit, pengelola Bimbel Prestasi, saat ini Bimbingan Belajar Prestasi sudah memiliki 38 cabang dengan rata-rata 125 siswa / cabang di seluruh Indonesia.

Melihat fenomena tersebut, penulis meneliti Strategi Komunikasi Pemasaran Lembaga Pelatihan dan Bimbingan Belajar (LPBB) Bintang Solusi Mandiri di tengah persaingan dengan kompetitor yang lainnya sebagai bagian dari peningkatan indeks pembangunan manusia melalui pendidikan yang memiliki filosofi, visi dan misi. Lembaga Pelatihan dan Bimbingan Belajar (Bimbel Solusi) Bintang Solusi Mandiri Cabang Cipinang merupakan cabang Franchise.

Tujuan penelitian ini untuk mengetahui strategi komunikasi pemasaran yang disampaikan oleh Kantor Solusi Pusat dan diimplementasikan oleh Bimbel Solusi Cipinang yang menurut mantan Quality Control (QC) Bimbingan Belajar Solusi Cipinang, Rohianingsih, S.Pd, Bimbel Solusi

$1 \mathrm{http} /$ www.pendidikanindonesia.com/2015/01/protret-dunia-pendidikan-di-indonesia. html di akses 19/11/2015, pukul 15.33 WIB 
Cipinang pernah mencapai 245 siswa di akhir tahun ajaran 2009/2010 dan sempat menjadi salah satu cabang Franchise percontohan saat itu.

Dengan melihat kondisi saat ini dan data penurunan jumlah siswa yang cukup signifikan yang ikut Lembaga Pelatihan dan Bimbingan Belajar Bintang Solusi Mandiri Cabang Cipinang pada tahun ajaran 2017/2018 bulan Agustus 2018 yaitu berjumlah 50 siswa dari tahun ajaran 2014/2015 yang berjumlah 125 dan sangat jauh menurun dibandingkan perolehan jumlah siswa di akhir tahun ajaran 2009/2010 yaitu mencapai 245 siswa di Lembaga Pelatihan dan Bimbingan Belajar Bintang Solusi Mandiri Cabang Cipinang, dan untuk mencapai jumlah siswa yang ideal yang berjumlah 200 siswa maka diperlukan suatu strategi komunikasi pemasaran dan folllow up yang lebih baik dibandingkan dari tahun ajaran sebelumnya.

Identifikasi masalah dalam penelitian ini adalah menurunnya kualitas sumber daya manusia Indonesia di tengah persaingan global, terbatasnya akses pendidikan masyarakat Indonesia, rendah lama harapan sekolah Indonesia sebagaimana peneliti ketahui bahwa pendidikan merupakan bagian dari peningkatan indeks pembangunan manusia melalui pendidikandalam menarik minat siswa di tengah persaingan dengan kompetitor.

Berdasarkan diidentifikasi masalah di atas diperoleh gambaran dimensi permasalahan. Namun menyadari adanya keterbatasan waktu dan kemampuan, maka penulis memandang perlu memberi batasan masalah secara jelas dan terfokus. Masalah yang menjadi obyek penelitian dibatasi hanya pada meneliti Strategi Komunikasi Pemasaran Lembaga Pelatihan dan Bimbingan Belajar (Bimbel Solusi) Bintang Solusi Mandiri Cabang Cipinang dalam meningkatkan jumlah siswa. Pembatasan masalah yang dimaksud adalah Cabang Cipinang saja yang sudah diteliti bulan Agustus 2018.

Berdasarkan data di atas dan persaingan yang semakin ketat, maka masalah yang muncul adalah menurunnya jumlah siswa yang ikut Lembaga Pelatihan dan Bimbingan Belajar Bintang Solusi Mandiri. Pertanyaan penelitian yang dapat dikembangkan antara lain: Bagaimana Strategi Komunikasi Pemasaran yang dilakukan Lembaga Pelatihan dan Bimbingan Belajar Bintang Solusi Mandiri Cabang Cipinang untuk dapat meningkatkan jumlah siswa ? dan Faktor - faktor apa saja yang mendukung Lembaga Pelatihan dan Bimbingan Belajar Bintang Solusi Mandiri Cabang Cipinang dalam Strategi Komunikasi Pemasaran untuk dapat meningkatkan jumlah siswa? Tujuan penelitian ini yaitu untuk mengetahui Strategi Komunikasi Pemasaran yang dilakukan oleh Lembaga Pelatihan dan Bimbingan Belajar Bintang Solusi Mandiri Cabang Cipinang dan untuk mengetahui faktor - faktor apa saja yang mendukung Lembaga Pelatihan dan Bimbingan Belajar Bintang Solusi Mandiri Cabang Cipinang dalam Strategi Komunikasi Pemasaran untuk dapat meningkatkan jumlah siswa.

\section{TINJAUAN PUSTAKA}

Strategi adalah penempatan misi instansi, penetapan sasaran organisasi dengan mengingat eksternal dan internal, perumusan kebijakan dan cara tertentu untuk mencapai sasaran dan memastikan implementasinya secara tepat, sehingga tujuan dan sasaran utama organisasi akan tercapai (Anshori, 2010: 18-20). Menurut R. Wayne Pace, Brent D. Peterson dan M. Dallas Burnet dalam bukunya Techniques for Effective Communication, ada empat tujuan dalam strategi komunikasi (Ruslan, 2008:37), sebagai berikut : 1) To secure understanding yaitu untuk memastikan bahwa terjadi suatu pengertian dalam berkomunikasi. 2) To establish acceptanceyaitu bagaimana cara penerimaan itu terus dibina dengan baik. 3)

To motivate action yaitu penggiat untuk memotivasinya. 4) To goals which communicator sought to achieve yaitu bagaimana mencapai tujuan yang hendak dicapai oleh pihak komunikator dari proses komunikasi yang berlangsung tersebut.

Strategi komunikasi pada hakekatnya adalah perencanaan (planning) dan manajemen (management) untuk mencapai satu tujuan. Untuk mencapai tujuan tersebut, strategi tidak berfungsi sebagai peta jalan yang hanya menunjukkan arah saja, melainkan harus menunjukkan bagaimana taktik operasionalnya. Menjelaskan pengertian komunikasi pemasaran dapat diuraikan melalui hubungan antara komunikasi dan pemasaran, sebab komunikasi pemasaran (marketing communication) adalah penggabungan dua kajian yaitu komunikasi (communication) dan pemasaran (marketing).

Secara umum, komunikasi pemasaran adalah kegiatan pemasaran dengan memanfaatkan teknik-teknik komunikasi yang ditujukan untuk memberikan informasi bagi orang banyak dengan harapan tercapainya tujuan perusahaan yakni peningkatan pendapatan (laba). 
Komunikasi pemasaran adalah proses penyampaian pesan dari komunikator ke komunikan melalui media dengan mengharapkan umpan balik berupa profit atau keuntungan tertentu. Menurut Sofjan Assauri (2013 : 15) berpendapat bahwa, strategi pemasaran adalah rencana yang menyeluruh, terpadu dan menyatu di bidang pemasaran, yang memberikan panduan tentang kegiatan yang akan dijalankan untuk dapat tercapainya tujuan pemasaran suatu perusahaan. Dengan kata lain, strategi pemasaran adalah serangkaian tujuan dan sasaran, kebijakan dan aturan yang memberi arah kepada usaha-usaha pemasaran perusahaan dari waktu ke waktu, pada masing-masing tanggapan perusahaan dalam menghadapi lingkungan dan keadaan persaingan yang selalu berubah.

Strategi pemasaran adalah cara dengan usaha tertentu dengan mengharapkan mendapatkan profit atau keuntungan tertentu. Strategi pemasaran sebagai alat fundamental yang direncanakan untuk mencapai tujuan perusahaan dengan mengembangkan keunggulan bersaing yang berkesinambungan melalui pasar yang dimasuki dan progran-program pemasaran yang digunakan untuk melayani pasar sasaran.

Menurut Philip Kotler (2009 :101) menyatakan bahwa Marketing Mix merupakan seperangkat alat pemasaran yang digunakan perusahaan untuk terus menerus mencapai tujuan pemasaranya di pasar sasaran. Mc Carthy dalam Kotler dan Keller (2009:63) mengklasifikasikan Marketing Mix menjadi empat besar kelompok yang disebut dengan 4P tentang pemasaran yaitu Product (produk), Price (harga), Place (tempat) dan Promotion (promosi).

Data yang dianalisis melalui pendekatan deskriptif kualitatif, yaitu dengan mengungkapkan data, menguraikan data dan dengan mendeskripsikan data yang diperoleh dari penelitian baik data primer maupun data sekunder dengan menggunakan bahasa yang mudah dimengerti dan dipahami kemudian data yang diperoleh diuraikan serta dikembangankan berdasarkan teori yang ada. Analisis data yang penulis gunakan adalah SWOT adalah akronim untuk kekuatan (Strenghts), kelemahan (Weakness), peluang (Opportunities), dan ancaman (Threats) dari lingkungan eksternal perusahaan.

Menurut Jogiyanto dalam Widharta (2013:6) menjelaskan bahwa analisis SWOT adalah semua organisasi memiliki kekuatan dan kelemahan dalam area fungsional bisnis. Tidak ada perusahaan yang sama kuatnya atau lemahnya dalam semua area bisnis. Kekuatan atau kelemahan internal, digabungkan dengan peluang dan ancaman dari eksternal dan pernyataan misi yang jelas, menjadi dasar untuk penetapan dengan maksud strategi. Tujuan dan strategi diterapkan dengan maksud memanfaatkan kekuatan internal dan mengatasi kelemahan.

\section{METODE PENELITIAN}

Sesuai dengan sifat dan karakter permasalahan data yang diangkat dalam penelitian ini, maka paradigma yang relevan dalam penelitian ini adalah paradigma Interprettif. Adapun pada tradisi kualitatif-interpretatif, manusia lebih dipandang sebagai makhkuk rohaniah alamiah (natural). Dalam pandangan ini, manusia sebagai makhluk sosial sehari-hari bukan "berperilaku" berkonotasi mekanistik alias bersifat otomatis seperti hewan, melainkan "bertindak" mempunyai konotasi tidak otomatis/mekanistik, melainkan humanistik alamiah : melibatkan niat, kesadaran, motif-motif, atau alasan-alasan tertentu, yang disebut Weber sebagai social action (tindakan sosial) dan bukan sosial behavior (perilaku sosial) karena ia bersifat intensional; melibatkan makna dan interpretasi yang tersimpan di dalam diri pelakunya. Dunia makna itulah yang perlu dibuka, dilacak, dan dipahami untuk bisa memahami fenomena sosial apa pun, kapan pun, dan dimana pun. (Vardiansyah 2008 : 67).

Metodologi penelitian komunikasi kualitatif-interpretif akan membawa pembahasan kembali ke rumpun ilmu-ilmu sosial. Dalam ilmu-ilmu sosial, Taylor dan Bogdan (1984) mendefinisikan metodologi kualitatif sebagai prosedur penelitian yang menghasilkan data deskriptif berupa kata-kata tertulis atau lisan dari orang atau gejala yang diamati. Pendekatan kualitatif-interpretif diarahkan pada latar gejala secara holistik (utuh menyeluruh) dan alamiah sehingga metodologi kualitatif tidak mengisolasikan gejala ke dalam variabel. Namun, mengkaji objeknya sesuai latar alamiahnya. Karenanya, lazim disebut juga penelitian alamiah/naturalistik. (Vardiansyah 2008 : 69). Penelitian kualitatif interpretif dengan menggunakan studi kasus.

Penelitian studi kasus berupaya menelaah sebanyak mungkin data mengenai subjek yang diteliti. Mereka sering menggunakan berbagai metode wawancara, pengamatan, penelaahan dokumen (hasil), survei, dan data apa pun untuk menguraikan suatu kasus secara terinci.

\section{HASIL DAN PEMBAHASAN}


LPBB BINTANG SOLUSI MANDIRI adalah perusahaan yang bergerak di bidang jasa pendidikan. Perusahaan ini didirikan di Jakarta oleh lima orang pemuda mahasiswa perguruan tinggi pada tanggal 4 Februari 2008. Lembaga pendidikan yang biasa disebut Bimbel Solusi ini memfokuskan diri pada pendidikan informal sekolah dalam bentuk kelompok belajar luar sekolah pada tingkat pendidikan dasar. (www.bintangsolusimandiri.com).

Bermula dari program belajar sederhana untuk siswa Sekolah Dasar kelas VI, Bimbel Solusi mulai diterima dan dipercaya untuk memberikan manfaat di masyarakat dan mengokohkan diri pada tahun-tahun selanjutnya. Keprihatinan dari para pendiri terhadap bimbingan belajar yang ada saat ini melatarbelakangi didirikannya Bimbel Solusi ini.

Pengembangan program-program bimbingan dilakukan untuk memenuhi kebutuhan dan membantu para siswa untuk meraih prestasi yang gemilang di sekolahnya. Konsep waralaba telah diterapkan sebagai strategi utama perluasan cabang. Dengan biaya yang terjangkau, fasilitas, dan kualitas yang memadai BIMBEL SOLUSI siap mencerdaskan kehidupan bangsa.

Filosofi LPBB Bintang Solusi Mandiri yaitu: "Membangun Pendidikan Berkarakter". Visi LPBB Bintang Solusi Mandiri yaitu: "Lembaga Pendidikan dan Pelatihan Terbesar, Terunggul dan Terpercaya di Indonesia". Misi LPBB Bintang Solusi Mandiri adalah: 1). Meningkatkan Metode Pengajaran, Mutu Pengajar, dan Materi Ajar yang berfokus pada Pembentukan Karakter melalui pelatihan dan penelitian, 2). Peningkatan Kapasitas dan Kemampuan SDM Pusat dan Cabang, 3). Memiliki SDM yang Unggul dan Profesional untuk memberikan pembinaan dibidang Manajemen, Pendidikan, dan Kewirausahaan, 4). Menjalankan Praktek Bisnis Beretika yang saling menguntungkan dengan Karyawan dan Mitra Bisnis, 5). Pengembangan disetiap Kotamadya dan Kabupaten secara bertahap mulai dari Pulau Jawa, Sumatra, dan seterusnya, dan 6). Membangun Kawasan Pendidikan yang memenuhi kebutuhan pendidikan masyarakat.

\subsection{Solusi Learning Class (SLC)}

Fasilitas Program SLC: 1). Buku Modul Belajar Seluruh Mata Pelajaran, 2). Buku Kerja Siswa (Bank Soal), 3). Buku Perjuangan (Buku Kontrol Siswa Harian), 4). Super Konsis (Konsultasi Siswa) Gratis, 5). Try Out Gratis, dan 6). Suplemen Lembar Soal.

\subsection{Strategi Komunikasi Pemasaran LPBB Bintang Solusi Mandiri Dimensi Kerja Kepala Cabang Berkaitan Dengan Divisi Marketing}

Marketing: 1). Daily; Mengevaluasi penambahan jumlah siswa dan melakukan upaya dalam bentuk kegiatan marketing untuk meningkatkan jumlah siswa, 2). Weekly; Mengevaluasi progress dan melakukan follow up dari setiap program marketing yang dilaksanakan, dan 3). Monthly; a). Mengevaluasi penambahan jumlah siswa, b). Mengevaluasi keberhasilan program marketing yang dijalankan, c). Membuat laporan kegiatan marketing dan laporan budgeting kegiatan marketing, dan d). Membuat dan menyampaikan kepada owner rencana kegiatan marketing dan budgeting kegiatan marketing.

\subsection{Standard Operating Procedure Marketing Bimbangan Belakar Solusi Rekrutmen Bimbel Solusi}

Kriteria Marketer terdiri dari : 1). Muslim/ah dan Menutup Aurat, 2). Jujur dan Bertanggung jawab, 3). Berani dan Percaya Diri, 4). Mampu bekerja di dalam tim, 5). Memiliki kemampuan Negosiasi dan Presentasi yang baik, dan 6). Memiliki Kendaraan bermotor (diutamakan).

\subsection{Proses Rekrutmen Marketer}

Tahapan Seleksi Terdiri dari : 1). Seleksi Administratif (CV dan Surat Lamaran), 2). Tes negosiasi dan presentasi, dan 3). Tes Interview.

\subsection{Penjelasan Tes Negosiasi dan Presentasi}

Presentasi terdiri dari : 1). Calon marketer diberikan waktu 10 menit untuk melakukan presentasi di depan penguji dan calon marketer yang lain. Bahan presentasi adalah knowledge product Bimbel SOLUSI yang sebelumnya sudah dijelaskan kepada calon marketer, 2). Yang dinilai adalah : a). 
Public Speaking, b). Intonasi, c). Body Language., 3). Format Penilaian menggunakan angka 1 (terendah) sampai 5 (tertinggi).

Negosiasi : Calon marketer diberikan waktu 10 menit untuk melakukan negosiasi (sebelumnya diberikan pengarahan terlebih dahulu). Penguji atau calon marketer lain berperan sebagai pihak sekolah yang menyulitkan diterimanya negosiasi.

Yang dinilai adalah : a). Kemampuan Negosiasi dan komunikasi, b). Kemampuann menghadapi keberatan-keberatan pihak sekolah, dan c). Sikap ketika bernegosiasi. Format penilaian menggunakan angka 1 (terendah) sampai 5 (tertinggi).

\subsection{Penjelasan Tes Interview}

Daftar Pertanyaan : 1). Mengapa mau bekerja di SOLUSI ?, 2). Mengapa memilih pekerjaan ini ?, 3). Apa yang dicari di dalam sebuah pekerjaan ?, 4). Mengapa tertarik di posisi ini ?, 5). Mengapa tertarik pada bimbel SOLUSI ?, 6). Apa pengalaman public speaking anda ?, dan 7). Apa pengalaman negosiasi anda?

Jobdesc Marketer : 1). Melakukan Negosiasi dan Presentasi ke Sekolah - sekolah yang menjadi target market cabang, 2). Menghadiri setiap briefing dan evaluasi yang diadakan oleh cabang, 3). Mengikuti setiap pelatihan marketing yang diadakan oleh cabang maupun Pusat, 4). Melakukan sebar brosur dan Direct Selling ke sekolah target ataupun sekitar cabang, 5). Membuat Action Plan harian marketer, 6). Mengisi papan monitor marketer, dan 6). Menaati seluruh peraturan marketer.

Hak Marketer : 1). Gaji Pokok Rp.100.000/pecan, 2). Gaji Harian Rp.20.000/hari (diberikan hanya jika masuk), 3). Bonus Presentasi Rp.2.000/kelas dipresentasikan, 4). Bonus target dan prestasi Rp.1.000.000 jika berhasil menggarap 100 siswa baru (Penjelasan lebih detail terdapat di surat akad marketer).

Waktu Kerja Marketer: Senin - Sabtu Pkl. 06.00-14.00 WIB

\subsection{Pelatihan Marketing}

Pelatihan Marketing Tahap I(Juni dan Desember) : 1). Product Knowledge, 2). Materi "Rahasia SUKSES Marketing Bimbel SOLUSI bag.1", 3). Teknik Presentasi dan Negosiasi, dan 4). Program Marketing Rekomendasi

\subsection{Pelatihan Marketing Tahap II (Juli dan Januari) : 1). Materi "Rahasia SUKSES Marketing} Bimbel bag.2”, 2). Evaluasi Seluruh Cabang, dan 3). Program marketing rekomendasi.

4.9. Sistem Controlling Marketer : 1). Briefing dan evaluasi harian, 2). Membuat action plan harian marketer, dan 3). Mengisi papan monitor marketer.

Berikut hasil wawancara penulis dengan informan mengenai strategi pemasaran Lembaga Pelatihan dan Bimbingan Belajar Bintang Solusi Mandiri Cabang Cipinang yaitu Presentasi Bimbel Solusi melalui Brosur ke kelas - kelas di beberapa Sekolah Dasar (SD) dan Sekolah Menengah Pertama (SMP), Direct Selling ke pemukiman dekat dengan cabang lalu follow up database calon siswa dan calon orang tua siswa melalui telpon dan Short Message Service (SMS). Seperti kata Pak Adam :

"Khusus bulan Agustus 2018 ini berjalan kurang efektif, Marketingnya Kurang efektif, Apa yang dilakukan yaitu sebar brosur ke sekolah - sekolah, lalu sebar brosur pun yang ke rumah rumah. Dan itupun. Di data setiap sekolah dapat berapa brosur untuk setiap orang di rumahnya. Setiap harinya marketer harus menyebar 50 brosur.Juga follow up via telpondan via SMS. Itu pun follow up database yang di dapat bulan Juli 2018”2.

\footnotetext{
${ }^{2}$ Wawacara dengan Pak Adam sebagai Kepala Cabang SOLUSI di Kantor Bimbingan Belajar Solusi Cipinang, pada tanggal 17 September 2018, pukul 10.00 WIB
} 
Berdasarkan wawancara penulis dengan informan mengenai faktor - faktor yag mendukung Lembaga Pelatihan dan Bimbingan Belajar Bintang Solusi Mandiri Cabang Cipinang dalam bidang Pemasaran yaitu Faktor program. Semakin banyak program, semakin banyak alternatif siswa untuk memilih,selain itu juga semakin banyak kesesuaian siswa, termasuk kesesuaianwaktu, seperti program konsultasi siswa (konsis) akan menambah minatbelajar bagi siswa sehingga dapat meningkatkan nilai akademik siswa. Seperti kata Pak Adam.

"Kita punya siswa yang sudah 5 sampai 6 tahun ikut terus les di Solusi salah satu alasannya karena sudah merasa kenal dan akrab dengan kakak - kakak Solusi. Kakak - kakaknya baik terus pinter juga, sudah akrab gitu sama kakak - kakaknya jadi kalau mau nanya PR atau nanya tugas itu udah seperti dengan kakak sendiri".Dan seperti kata Pak Adam lagi "Kalau dari orang tua siswa merasa nyaman karena ada Fasilitas Konsultasi Siswa (Konsis) dan dibantu proses pada saat tahun ajaran baru baik di sekolah, lalu saat siswa naik ke kelas 6 SD kita bantu juga proses pendaftaran ke SMP jadi menimbulkan kesan yang baik ke orang tua".3

Penambahan program try out akbar dan jalan-jalan ke Trans Studio Bandung yang merupakan diferensiasi produk diharapkan siswa tidak bosan mengikuti proses belajar di lingkungan Bimbingan Belajar Solusi Cabang Cipinang. Selain itu, di DKI Jakarta selain faktor nama besar dan harga merupakan faktor paling utama akan menambah minat siswa untuk mendaftar. Kemudian faktor dukungan dana yang cukup untuk promosi dan didukung dengan kualitas tutor yang bagus, produk bervariasi dan harga yang terjangkau akan dapatmeningkatkan jumlah siswa. Faktor lokasi yang cukup strategis yang dilewati angkutan umum sehingga mudah diakses calon siswa dan calon orang tua siswa. Dari penelitian sampai bulan Agustus 2018 terjadi sedikit penurunan siswa dari tahun kemarin pada bulan yang sama, hal tersebut disebabkan ada salah satu faktor yaitu SD Kemala Bhayangkari yang mengadakan bimbingan belajar di dalam sekolah, persaingan dengan Bimbingan Belajar Solusi cabang Rawamangun.

Faktor - faktor yang mendukung Lembaga Pelatihan dan Bimbingan Belajar Bintang Solusi Mandiri Cabang Cipinang dalam strategi komunikasi pemasaran yaitu lokasi yang strategis yang dekat dengan beberapa Sekolah Dasar (SD) dan dilalui angkutan umum cukup mempermudah pencarian lokasi dan harga sewa tempat yang terjangkau sehingga mempermudah memberikan potongan harga tambahan kepada calon siswa. Seperti kata Pak Adam jelaskan bahwa :

"Yang pertama sebenarnya posisi cukup strategis karena lokasi di Pinggir jalan, walaupun di perumahan. Terus yang kedua lokasi Dilalui transportasi KWK 26 jurusan Rawamangun Klender - Kalimalang itu pun juga menjadi target atau sasaran wilayah Solusi Cipinang yaitu Klender, Cipinang itu sendiri, Jatinegara Kaum maupun Rawamangun. Yang ketiga posisi cabang kita lebih luas dari cabang yang lain.Yang keempat biaya sewa kita lebih murah dari cabang yang lain". ${ }^{4}$

Faktor - faktor yang mendukung Lembaga Pelatihan dan Bimbingan Belajar Bintang Solusi Mandiri Cabang Cipinang dalam strategi komunikasi pemasaran bulan Oktober 2018 yaitu pemanfaatan karyawan internal menjadi marketer di fase marketing berikutnya menjadi penting dikarenakan karyawan internal lebih mengenal product knowledge dibandingkan dari eksternal. Seperti kata Pak Adam yang jelaskan :

"Untuk persiapan bulan Oktober marketingnya kayaknya kita masih memanfaatkan SDM yang ada di dalam atau internal. Kemarin kita Kita sudah mendapat $2-3$ orang, tapi yang baru fiksasi baru 2 orang.Untuk yang lebih dimanfaatkan di bulan Januari kita masih Memanfaatkan internal". 5

\footnotetext{
${ }^{3}$ Wawacara dengan Pak Adam sebagai Kepala Cabang SOLUSI di Kantor Bimbingan Belajar Solusi Cipinang, pada tanggal 17 September 2018, pukul 10.00 WIB

${ }^{4}$ Wawacara dengan Pak Adam sebagai Kepala Cabang SOLUSI di Kantor Bimbingan Belajar Solusi Cipinang, pada tanggal 17 September 2018, pukul 10.00 WIB

${ }^{5}$ Wawacara dengan Pak Adam sebagai Kepala Cabang SOLUSI di Kantor Bimbingan Belajar Solusi Cipinang, pada tanggal 17 September 2018, pukul 10.00 WIB
} 
Faktor - faktor yang mendukung Lembaga Pelatihan dan Bimbingan Belajar Bintang Solusi Mandiri Cabang Cipinang dalam strategi komunikasi pemasaran bulan Oktober 2018 yaitu presentasi melalui brosur Bimbel Solusi ke kelas - kelas di sekolah dan pemberian share pembangunan ke sekolah sebagai wujud kepedulian Lembaga Pelatihan dan Bimbingan Belajar Bintang Solusi Mandiri Cabang Cipinang terhadap pendidikan Indonesia. Seperti kata Pak Adam yang dijelaskan oleh beliau:

"Untuk marketing bulan Oktober kemungkinan besar kita akan ke Sekolah - sekolah yang belum kita kunjungi dan sekolah - sekolah yang belum tembus sama sekali kita dengan strategi share pembangunan sekolah di mana bisa menarik di sekolah tersebut jadi ibaratnya ketika kita masuk kita sudah memegang data siswa tersebut Jadi ketika kita masuk ke sekolah kita megang datanya kemungkinan besar ketika kita sudah memegang data si anak tersebut data sekolah tersebut siswa yang masuk dari sekolah itu ke Bimbingan Belajar Solusi bisa diakses gitu menuju sekolah tersebut". ${ }^{6}$

Berdasarkan hasil penelitian sesuai dengan teori yang disampaikan oleh peneliti Mc Carthy dalam Kotler dan Keller (2009:63) mengklasifikasikan Marketing Mix menjadi empat besar kelompok yang disebut dengan 4P tentang pemasaran yaitu Product (produk), Price (harga), Place (tempat) dan Promotion (promosi). Strategi pemasaran Lembaga Pelatihan dan Bimbingan Belajar Bintang Solusi Mandiri Cabang Cipinang yaitu Presentasi Bimbel Solusi melalui Brosur ke kelas - kelas di beberapa Sekolah Dasar (SD) dan Sekolah Menengah Pertama (SMP), Direct Selling ke pemukiman dekat dengan cabang lalu follow up database calon siswa dan calon orang tua siswa melalui telpon dan Short Message Service (SMS). Di data setiap sekolah dapat berapa brosur untuk setiap orang di rumahnya. Setiap harinya marketer harus menyebar 50 brosur dan follow up via telpon dan via SMS follow up database yang di dapat bulan Juli 2018". Menurut Morrison dalam Dewi (2010:209) konsep Marketing Mix diperluas menjadi 8P, dengan penambahan People, Packaging, Partnership, dan Programming.

Faktor - faktor yang mendukung Lembaga Pelatihan dan Bimbingan Belajar Bintang Solusi Mandiri Cabang Cipinang dalam bidang Pemasaran yaitu Faktor program. Semakin banyak program, semakin banyak alternatif siswa untuk memilih,selain itujuga semakin banyak kesesuaian siswa, termasuk kesesuaianwaktu, seperti program konsultasi siswa (konsis) akan menambah minat belajar bagi siswa sehingga dapat meningkatkan nilai akademik siswa. Kemudian penambahan program try out akbar dan jalan-jalan ke Trans Studio Bandung yang merupakan diferensiasi produk diharapkan siswa tidak bosan mengikuti proses belajar di lingkungan Bimbingan Belajar Solusi Cabang Cipinang. Kemudian faktor dukungan dana yang cukup untuk promosi dan didukung dengan kualitastutor yang bagus, produk bervariasi dan harga yang terjangkau akan dapatmeningkatkan jumlah siswa.

Faktor lokasi yang cukup strategis yang dilewati angkutan umum sehingga mudah diakses calon siswa dan calon orang tua siswa. Dari penelitian sampai bulan Agustus 2018 Solusi Cipinang sebanyak 50 siswa terjadi sedikit penurunan siswa dari tahun kemarin pada bulan yang sama yaitu berjumlah 60 siswa, hal tersebut disebabkan ada salah satu faktor yaitu SD Kemala Bhayangkari yang mengadakan bimbingan belajar di dalam sekolah, persaingan dengan Bimbingan Belajar Solusi cabang Rawamangun.

Posisi Solusi Cipinang cukup strategis karena lokasi di pinggir jalan, walaupun di perumahan. Kemudian yang kedua lokasi dilalui transportasi KWK 26 jurusan Rawamangun - Klender Kalimalang itu pun juga menjadi target atau sasaran wilayah Solusi Cipinang yaitu Klender, Cipinang itu sendiri, Jatinegara Kaum maupun Rawamangun. Lalu yang ketiga posisi cabang lebih luas dari cabang yang lain. Kemudian yang keempat biaya sewa kita lebih murah dari cabang yang lain.

Pada bulan Oktober Marketing akan ke Sekolah - sekolah yang belum dikunjungi dan sekolah - sekolah yang belum tembus sama sekali dengan strategi share pembangunan sekolah di mana bisa menarik di sekolah tersebut. Ini berarti marketer sudah memegang data siswa tersebut jadi ketika marketer masuk ke sekolah marketer telah memegang datanya. Kemungkinan besar ketika marketer sudah memegang data si anak, data sekolah tersebut siswa yang masuk dari sekolah itu ke Bimbingan Belajar Solusi bisa diakses menuju sekolah tersebut.

${ }^{6}$ Ibid 
Faktor harga yang terjangkau menjadi perhatian mengingat kompetitor Bimbel Kalia Cipinang mempunyai harga yang lebih terjangkau dari Bimbel Solusi Cipinang. Faktor tempat yang berdekatan antara Bimbingan Belajar Solusi cabang Cipinang dengan Bimbingan Belajar Solusi cabanng Rawamangun menjadi "kompetitor" tersendiri meskipun "satu bendera".

Menurut Morrison dalam Dewi (2010:209) menyatakan bahwa konsep Marketing Mix diperluas menjadi 8P, dengan penambahan People,packaging, Partnership, dan Programming menyatakan bahwa faktor program yang menarik seperti wisata edukasi sekaligus refreshing ke luar kota menjadi program yang menarik minat calon siswa untuk mendaftar.

\section{SIMPULAN}

Simpulan yang didapat dari penelitian ini adalah: Strategi Pemasaran Lembaga Pelatihan dan Bimbingan Belajar Bintang Solusi Mandiri Cabang Cipinang bulan Agustus 2018 yaitu Direct Selling ke pemukiman warga memperkenalkan Bimbingan Belajar (Bimbel) Solusi melalui brosur, Presentasi Bimbel Solusi tiap kelas di sekolah - sekolah melalui brosur, Pembagian share pembangunan sekolah sebesar Rp.50.000 / siswa yang bergabung Bimbel Solusi Cabang Cipinang, follow up database siswa di sekolah melalui telpon dan short message service (SMS).

Faktor - faktor yang mendukung Lembaga Pelatihan dan Bimbingan BelajarBintang Solusi Mandiri Cabang Cipinang dalam bidang Strategi Komunikasi Pemasaran untuk dapat meningkatkan jumlah siswa yaitu faktor program. Program try out akbar dan jalan-jalan ke Trans Studio Bandung yang merupakan diferensiasi produk. Kemudian faktor dukungan dana yang cukup untuk promosi dan didukung dengan kualitas tutor yang bagus, produk bervariasi dan harga yang terjangkau akan dapat meningkatkan jumlah siswa dan faktor lokasi yang strategis. Dari penelitian sampai bulan Agustus 2018 terjadi sedikit penurunan siswa disebabkan ada salah satu faktor yaitu persaingan dengan Bimbingan Belajar Solusi cabang Rawamangun.

\section{DAFTAR PUSTAKA}

Anshori, Y. (2010). Tourism Board : Strategi Promosi Pariwisata Daerah. Surabaya : ITS Press Assauri, Sofjan. (2013). Manajemen Pemasaran. Jakarta : Rajawali Pers.

Bungin, Burhan, (2010), Penelitian Kualitatif : Komunikasi, Ekonomi,Kebijakan Publik dan Ilmu Sosial lainnya. Jakarta: Kencana Prenama Media

Dewi, M. (2010), Teori dan Pengukuran Pengetahuan, Sikap dan Perilaku Manusia..Yogyakarta : Nuha Medika.

Kotler, Philips. (2009) . Manajemen Pemasaran Jilid 2. Terjemahan Drs. Benyamin $\quad$ Molan. PT Indeks Kelompok Gramedia

Paul Watzlawick, Janet Beavin, dan Don Jackson. (2011), Pracmatics of Human Communication, dalam Littlejohn dan Foss, Thomson Wadsworth, Belmont

Ruslan,Rosady. (2008). Manajemen Public Relations \& Media Komunikasi.Jakarta : PT Rajagrafindo Persada.

Stephen W. Littlejohn dan Karen A. Foss, 2008. Theories of Human Communication, Ninth

Edition, Thomson Wadsworth, Belmont.

Syamsu, Yusuf. 2006. Psikologi Perkembangan Anak dan Remaja. Bandung : Remaja Rosdakarya

\section{Sumber lain :}

http://www.pedidikanindonesia.com/2015/01/potret-dunia-pendidikan-diakses 19/11/2015 Pukul 15:33 WIB

indonesia.html di 